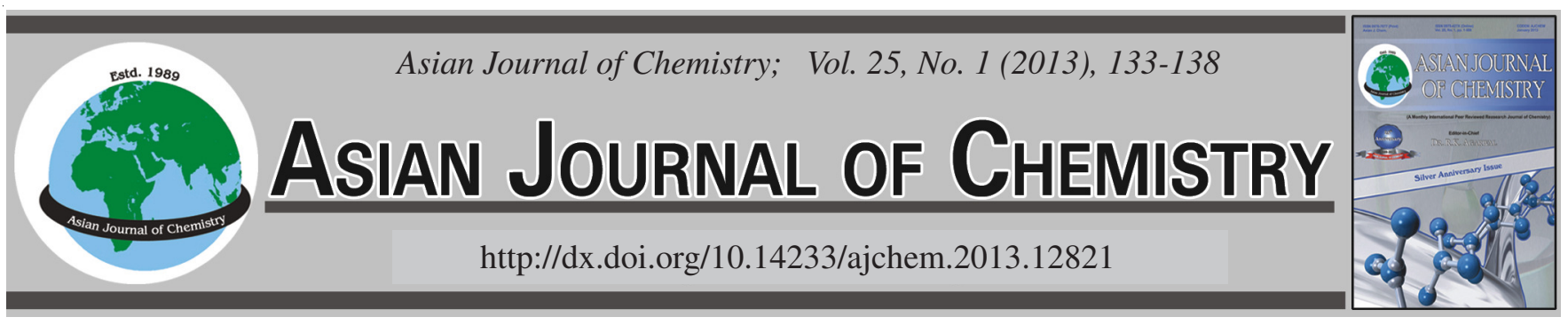

\title{
Chemical and Mineralogical Characterization of Old Mortars from Jahangir Tomb, Lahore-Pakistan
}

\author{
S. Gulzar ${ }^{1, *}$, M.N. Chaudhry ${ }^{1}$ and Jean-PIERre Burg ${ }^{2}$
}

${ }^{1}$ College of Earth and Environmental Sciences, University of the Punjab, Lahore-54590, Pakistan

${ }^{2}$ Swiss Federal Institute of Technology, Zurich Geological Institute, NO E 67, Sonneggstrasse 5, CH-8092 Zurich, Switzerland

*Corresponding author: Fax: +92 42 35831866; Tel: +92 42 35855827; E-mail: saimagulzar@yahoo.com

\begin{abstract}
The $17^{\text {th }}$ century tomb of the Mughal Emperor Jahangir has suffered several conservation and restoration interventions throughout its existence, without any systematic previous knowledge of the chemistry and mineralogy of old mortars. The characterization involved a multidisciplinary set of chemical, physical and micro-structural techniques, particularly X-ray fluorescence spectrometry and scanning electron microscopy equipped with EDS detector to determine the chemical composition of the mortars, which provides necessary information for compatible mortars as well as the state of conservation. The XRD and petrographic studies results show that the mortars were a variable mixture of burnt lime and fine Ravi river sand. The binder being the calcitic lime was obtained from kankar (lime nodules) abundantly found in zone B of Lahore soils and in its surrounding area which contains $70 \% \mathrm{CaCO}_{3}, 30 \%$ clay and a fraction of sand with other impurities. The aggregates used were sand, brick pieces and broken kankar. Surkhi (pulverized brick) and rarely slag were used as pozzolanic materials to increase the strength of the mortars.
\end{abstract}

Key Words: Mughal architecture, Conservation, XRF, SEM-EDS, Petrography, XRD, Pozzolana, Kankar.

\section{INTRODUCTION}

Jahangir tomb is one of the majestic monuments, which represent the glorious architectural era of the Mughal architecture in the subcontinent (Pakistan and India). The construction of Jahangir tomb dates back to the $17^{\text {th }}$ century and was built on Persian traditions ${ }^{1}$ constituting of tomb building in the center of walled garden locally known as Chahar-Bagh ${ }^{2}$. The garden is divided into four gardens which are further divided into four, thereby splitting the whole into sixteen segments. These segments are separated by walkways and water channels which are elaborately decorated with geometric patterns, fountains and cascades.

The walled tomb garden (Fig. 1a) is entered from the west through a monumental gateway in the eastern wall of a forecourt (Akbari Serai) that also featured external gates on the north and south with a mosque on the west in perfect symmetry $^{3}$. At the center of the approximately 500 meters square garden (600 gaz square) is the stone-clad tomb itself, surmounted at each corner by a minaret reaching heights of approximately $30 \mathrm{~m}^{1,3}$.

The aim of the present work is to characterize the old mortars for the development of integrated conservation strategies for future restoration works.

\section{EXPERIMENTAL}

Sampling methodology: The sampling of mortars is a crucial step that can influence the success of the characterization methodology $y^{4}$. The selection of the sampling sites was made with the help of in-charge conservator/technicians and according to the previous research methodologies ${ }^{5}$ adopted internationally ${ }^{6}$. Seven mortars were sampled from different sites as shown in Fig. 1b and described in Table-1.

Preliminary observations showed that samples SJT1, SJT3, SJT6 and SJT7, which were taken from wall sections composed of one layer with variable thicknesses. The samples were dirty white in colour and showed pieces of kankar, brick and fibrous material.

Megascopic observations of sample SJT2 revealed two distinct layers, one inner layer inside the masonry of dirty white colour with variable grain size distribution designated as SJT21 while the other layer facing outwards was of light reddish colour with fine grains with no fibers. This layer seems to be later addition as it was applied to fill the deteriorated masonry and designated as SJT2-2.

Samples SJT4 and SJT5 are composed of one uniform layer thickness with pale white colour. The samples showed small pieces of kankar, brick and slag strongly adhered to the substrate. The fibers were also found in these samples. 


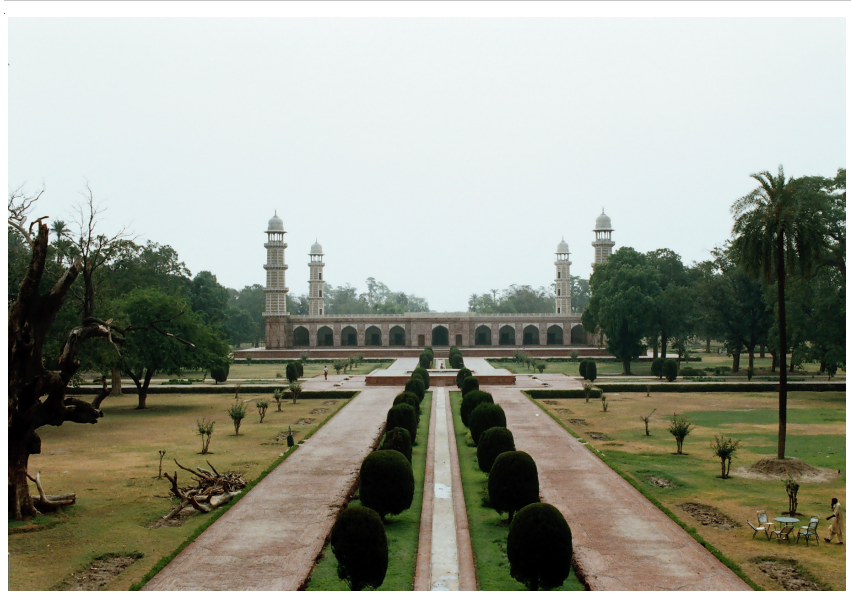

Fig. 1. (a) Aerial view of the Jahangir Tomb with Chahar-bagh setting

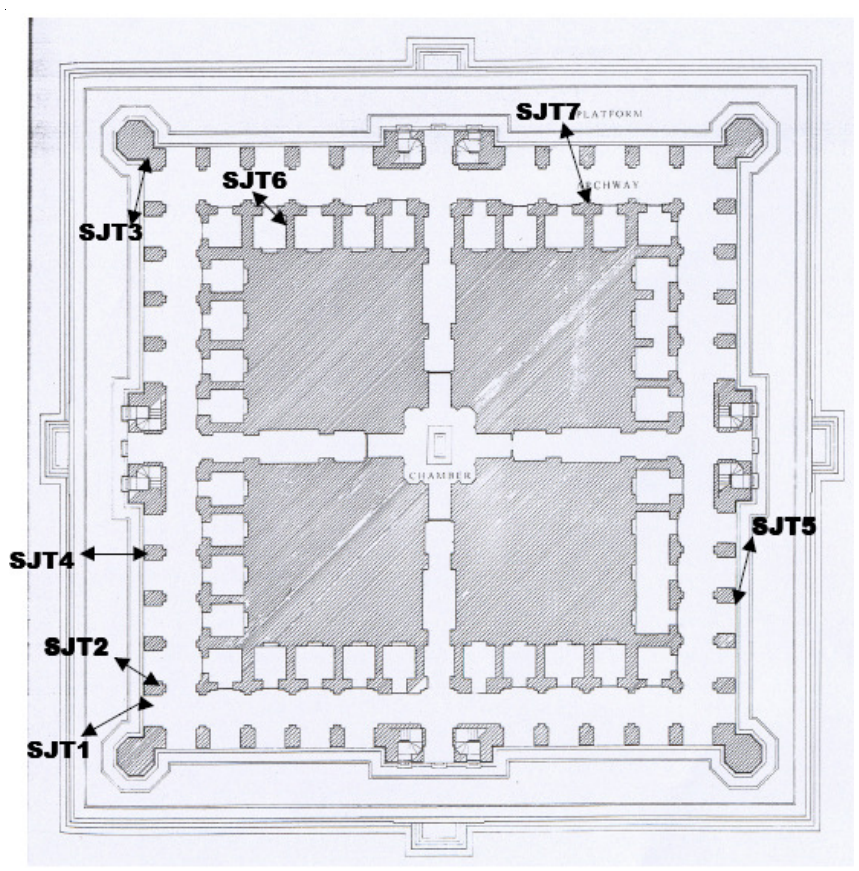

Fig. 1. (b) Plan of the Jahangir Tomb and sampling sites indicated on the plan

\begin{tabular}{lll} 
& \multicolumn{2}{c}{ TABLE-1 } \\
\multicolumn{3}{c}{ DESCRIPTION OF THE OLD MORTAR SAMPLES } \\
\hline Sample & Mortar Function & Location \\
\hline SJT1 & Filler Mortar & Inner wall of archways \\
SJT2-1 & Filler Mortar & External wall of archways \\
SJT2-2 & Filler Mortar-new & External wall of archways \\
SJT3 & Filler Mortar & Inner shaft wall of minaret \\
SJT4 & Render & Exterior wall front facade \\
SJT5 & Render & Exterior wall rear facade \\
SJT6 & Filler Mortar & Inner wall of rooms \\
SJT7 & Filler Mortar & External wall of rooms \\
\hline
\end{tabular}

Characterization methodology: Prior to chemical characterization, the samples were studied petrographically and by XRD to determine the mineral phases present in thin sections ${ }^{6-8}$. The mortars were thoroughly examined using a petrographic polarizing microscope to determine the binder, aggregate and additives used in the past and to characterize them for future conservation works.

$\mathrm{X}$-ray diffraction was carried out using Ni-filtered $\mathrm{CuK}_{\alpha}$ radiation, with a step size of $0.05^{\circ}$ at $2 \mathrm{sec}$ per point and $2 \theta$ ranging from $5^{\circ}$ to $60^{\circ}$. Two types of fractions were analyzed, the fraction corresponding to the mortar as collected, designated as overall fraction and the other fraction designated as insoluble residues fraction, which was obtained after the acid digestion of the mortar samples to determine the siliceous aggregates from the lime paste.

The powdered samples were also used to make fused glass-beads (sample powder with lithium tetraborate in 1:5 ratios) for X-ray fluorescence spectrometry. The pills were analyzed with wavelength dispersive X-ray fluorescence spectrometer (WD-XRF, Axios, PANalytical), equipped with 5 diffraction crystals to establish the overall chemical composition of the mortars necessary for developing the compatible repair mortars.

In addition, polished sections were also prepared from vacuum impregnated samples in epoxy resin. They were analyzed by scanning electron microscope, JEOL JSM 6390 LA coupled with EDS (EDS, Oxford-1 NCA) spectrometer for texture imaging and bulk chemical compositional analysis.

\section{RESULTS AND DISCUSSION}

Preliminary observations of the polished sections under a petrographic polarizing microscope showed that all the mortars contains lime nodules (kankar), which indicate that the burnt lime was slaked with a minimum amount of water to convert $\mathrm{CaO}$ into $\mathrm{Ca}(\mathrm{OH})_{2}$ with a release of energy ${ }^{9-11}$.

$$
\mathrm{CaO}+\mathrm{H}_{2} \mathrm{O} \rightarrow \mathrm{Ca}(\mathrm{OH})_{2}+65.5 \mathrm{~kJ}
$$

The samples were heterogeneous and the aggregates showed different colour, shape and sizes ${ }^{9}$. The aggregate content was very small, approximately 1.5-2.5 times of the binder content as compared to the new modern mortars applied in 20th century where it is 5-6 times as determined in sample SJT2-2 $2^{12,13}$. The sand used was fine Ravi river sand in these mortars as observed under the microscope. Lime nodules in the form of broken kankar pieces were observed in all the samples with the exception of the sample of mortar added in later periods (SJT2-2).

Observation of thin sections (Fig. 2) showed that samples SJT1, SJT2-1, SJT3, SJT6 and SJT7 are almost identical with a binder composed mainly of a carbonate phase ${ }^{14}$. The largest fraction of the aggregates consists of kankar-carbonate, crushed bricks and sand with jute fibers added as an additive ${ }^{15,16}$. This observation is further supported by the geology of the area. The kankar were extracted from the B-horizon of soil profile in addition to the high level river terraces around the cities of Lahore and Kasur ${ }^{15,16}$. It was also possible to observe microcrystalline phases of silica. The subangular to subrounded quartz grains embedded in the binder content are mainly silt sized to very fine sand sized as observed in the thin sections. The petrographic studies showed that the sand used in these mortars correlates mineralogically with Ravi sand which is the local source within the vicinity ${ }^{15}$. The fibrous material was also observed and found to be the jute fiber locally available and was used to increase the bonding strength of the constituents of the mortars.

The XRD results showed that the mortars are essentially composed of carbonate (calcite) and siliceous aggregates (Table-2) confirming the optical observations. The presence 


\begin{tabular}{|c|c|c|c|c|c|c|c|c|}
\hline \multicolumn{9}{|c|}{$\begin{array}{l}\text { TABLE-2 } \\
\text { MINERALOGICAL COMPOSITION OF THE MORTARS ASSESSED BY XRD }\end{array}$} \\
\hline Crystalline phases & SJT1 & SJT2-1 & SJT2-2 & SJT3 & SJT4 & SJT5 & SJT6 & SJT7 \\
\hline Calcite & +++ & +++ & ++ & +++ & +++ & $++/+++$ & +++ & $++/+++$ \\
\hline Quartz & ++ & ++ & +++ & ++ & $++/+++$ & ++ & $++/+++$ & $++/+++$ \\
\hline Illite/ Clay & ++ & +++ & $+/-$ & ++ & $+/++$ & + & ++ & $+/++$ \\
\hline Albite & $+/-$ & + & $+/-$ & - & $?$ & $-/+$ & $-/+$ & $-/+$ \\
\hline Haematite & + & + & + & $\mathrm{t}$ & + & $t /+$ & + & + \\
\hline Gypsum & $+/-$ & + & $t$ & $\mathrm{t}$ & $t /-$ & + & + & + \\
\hline Halite & $?$ & + & - & $?$ & $\mathrm{t}$ & $? / \mathrm{t}$ & $?$ & - \\
\hline
\end{tabular}

TABLE-3

CHEMICAL COMPOSITION OF MORTARS DETERMINED BY XRF-SPECTROSCOPY (wt \%) EXPRESSED IN OXIDES

\begin{tabular}{|c|c|c|c|c|c|c|c|c|c|}
\hline \multirow{2}{*}{ Sample } & \multirow{2}{*}{ wt $\%$} & \multirow{2}{*}{ SJT1 } & \multicolumn{2}{|c|}{ SJT2 } & \multirow{2}{*}{ SJT3 } & \multirow{2}{*}{ SJT4 } & \multirow{2}{*}{ SJT5 } & \multirow{2}{*}{ SJT6 } & \multirow{2}{*}{ SJT7 } \\
\hline & & & SJT2-1 & SJT2-2 & & & & & \\
\hline $\mathrm{SiO}_{2}$ & wt $\%$ & 23.742 & 22.893 & 44.718 & 25.916 & 21.342 & 20.984 & 22.836 & 24.042 \\
\hline $\mathrm{TiO}_{2}$ & wt $\%$ & 0.321 & 0.275 & 0.44 & 0.369 & 0.3 & 0.294 & 0.509 & 0.442 \\
\hline $\mathrm{Al}_{2} \mathrm{O}_{3}$ & wt $\%$ & 6.706 & 5.174 & 8.106 & 6.007 & 5.49 & 5.282 & 6.837 & 7.361 \\
\hline $\mathrm{Fe}_{2} \mathrm{O}_{3}$ & wt $\%$ & 3.507 & 2.301 & 3.507 & 2.757 & 2.551 & 2.285 & 2.675 & 2.322 \\
\hline $\mathrm{FeO}$ & wt $\%$ & 0 & 0 & 0 & 0 & 0 & 0 & 0 & 0 \\
\hline $\mathrm{MnO}$ & wt $\%$ & 0.082 & 0.066 & 0.082 & 0.06 & 0.028 & 0.068 & 0.096 & 0.057 \\
\hline $\mathrm{MgO}$ & wt $\%$ & 2.404 & 1.61 & 2.304 & 1.954 & 2.36 & 1.555 & 2.177 & 1.364 \\
\hline $\mathrm{CaO}$ & wt $\%$ & 30.039 & 33.804 & 20.139 & 30.505 & 35.34 & 35.932 & 32.304 & 31.067 \\
\hline $\mathrm{Na}_{2} \mathrm{O}$ & wt $\%$ & 1.245 & 0.883 & 1.245 & 1.855 & 0.866 & 1.249 & 1.549 & 1.68 \\
\hline $\mathrm{K}_{2} \mathrm{O}$ & wt $\%$ & 1.619 & 1.147 & 2.619 & 1.728 & 0.601 & 1.127 & 1.734 & 1.246 \\
\hline $\mathrm{P}_{2} \mathrm{O}_{5}$ & wt $\%$ & 0.107 & 0.113 & 0.507 & 0.367 & 0.07 & 0.088 & 0.033 & 0.106 \\
\hline $\mathrm{Cr}_{2} \mathrm{O}_{3}$ & wt $\%$ & 0.087 & 0.011 & 0.187 & 0.021 & 0.005 & 0.006 & 0.013 & 0.007 \\
\hline $\mathrm{NiO}$ & wt $\%$ & 0.002 & 0.006 & 0.012 & 0.007 & 0.003 & 0.003 & 0.005 & 0 \\
\hline $\mathrm{H}_{2} \mathrm{O}$ & wt $\%$ & 0 & 0 & 0 & 0 & 0 & 0 & 0 & 0 \\
\hline $\mathrm{CO}_{2}$ & wt $\%$ & 0 & 0 & 0 & 0 & 0 & 0 & 0 & \\
\hline LOI & wt $\%$ & 29.894 & 31.55 & 15.894 & 28.454 & 31.044 & 30.785 & 29.232 & 30.306 \\
\hline Total & & 99.755 & 99.833 & 99.76 & 100 & 100 & 99.658 & 100 & 100 \\
\hline
\end{tabular}

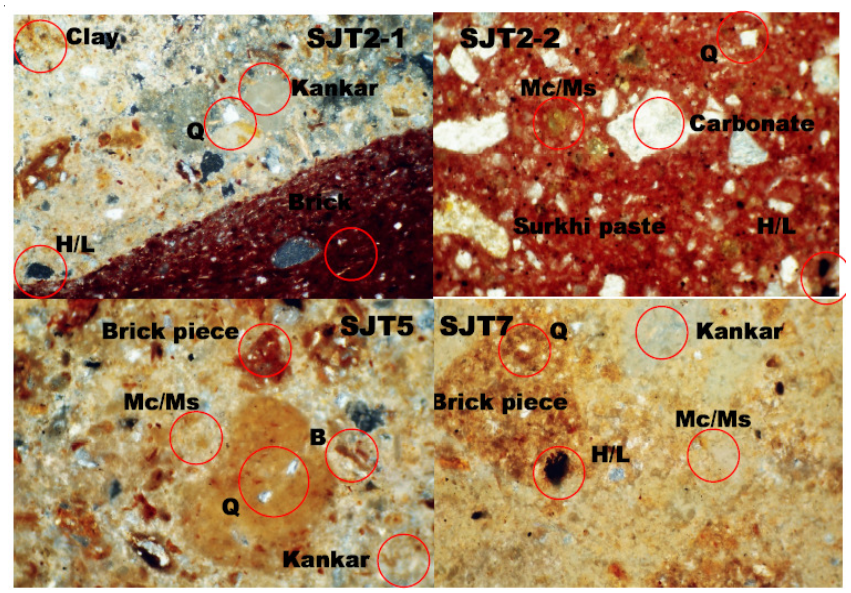

Fig. 2. Thin-section observation of the mortars with a stereomicroscope, showing brick pieces, kankar-lime and siliceous aggregates

of halite in the samples suggested its use as an accelerator for the mortars carbonation and gypsum in traces indicates the chemical deterioration of the mortar which is considered as the later developments ${ }^{17,18}$.

The XRD analysis of insoluble residues fraction clearly indicated the fine sand content which supports the optical studies and the use of nearby Ravi sand which is mineralogically found the same as in the samples.

The samples SJT4 and SJT5, which were used as renders rich in recrystallized calcite also showed the presence of slag in addition to surkhi and kankar. These renders showed recrystallized $\mathrm{CaCO}_{3}$ as the carbonation can also occur as shown in the equations below when the render is hard as often observed in the old mortars and renders ${ }^{19-21}$.

$$
\begin{gathered}
\mathrm{Ca}(\mathrm{OH})_{2}+\mathrm{CO}_{2} \rightarrow \mathrm{CaCO}_{3} \\
\mathrm{CO}_{2}+\mathrm{H}_{2} \mathrm{O} \rightarrow \mathrm{H}_{2} \mathrm{CO}_{3} \\
\mathrm{CaCO}_{3}+\mathrm{H}_{2} \mathrm{CO}_{3} \rightarrow \mathrm{Ca}\left(\mathrm{HCO}_{3}\right)_{2}(\text { soluble }) \\
\mathrm{Ca}\left(\mathrm{HCO}_{3}\right)_{2}+\mathrm{Ca}(\mathrm{OH})_{2} \rightarrow \mathrm{CaCO}_{3}
\end{gathered}
$$

These render mortars are very fine grained due to the fine aggregates used with fibers forming a monolithic mass. The slag used in these samples was brick kiln slag as described in textural references ${ }^{22-24}$.

For all the samples, the insoluble residues observed under a microscope together with XRD analysis confirmed that the aggregates used have uniform mineralogical composition. It was also possible to verify the presence of surkhi and fibrous material.

The chemical composition of mortars as oxides determined by XRF spectrometry (in wt. \%) is shown in Table-3. The results revealed remarkably uniform composition for all the mortars except SJT2-2. The mortars were mainly composed of $\mathrm{CaO}$ ranging from $50-60 \%$ and $\mathrm{SiO}_{2}$ about $25 \%$ with $\mathrm{Al}_{2} \mathrm{O}_{3}$ content of $7 \%$, which is higher due to the crushed brick added as an aggregate. The $\mathrm{Fe}_{2} \mathrm{O}_{3}$ content is 2-3\%, which is the characteristics of the historic lime mortars used in the past. The $\mathrm{Na}_{2} \mathrm{O}$ and $\mathrm{K}_{2} \mathrm{O}$ values range from $1-2 \%$ while $\mathrm{MgO}$ content is almost $2 \%$ in all the samples due to its occurrence as a subordinate phase with calcite $\left(\mathrm{CaCO}_{3}\right)$. 


\begin{tabular}{|c|c|c|c|c|c|c|c|c|c|}
\hline \multicolumn{10}{|c|}{$\begin{array}{l}\text { TABLE-4 } \\
\text { CHEMICAL COMPOSITION OF MORTARS DETERMINED BY SEM-EDS AVERAGED (wt \%) }\end{array}$} \\
\hline Sample & & T1 & & & SJT3 & SJT4 & SJT5 & SJT6 & SJT7 \\
\hline Oxides & wt $\%$ & & SJT2-1 & SJT2-2 & & & & & \\
\hline $\mathrm{Na}_{2} \mathrm{O}$ & wt $\%$ & 1 & 1.16 & 0.35 & 1.35 & 1 & 1.71 & 1.35 & 1.43 \\
\hline $\mathrm{MgO}$ & wt $\%$ & 3 & 2.57 & 2.76 & 2.5 & 4 & 3.25 & 3 & 2.36 \\
\hline $\mathrm{A}_{12} \mathrm{O}_{3}$ & wt $\%$ & 6 & 6.55 & 9.52 & 5 & 4.5 & 7.7 & 6.75 & 8.17 \\
\hline $\mathrm{SiO}_{2}$ & wt $\%$ & 27 & 27.62 & 50.7 & 25 & 23 & 24.75 & 25.25 & 33.9 \\
\hline $\mathrm{P}_{2} \mathrm{O}_{5}$ & wt $\%$ & 0.1 & 0.1 & 0 & 0.1 & 0.2 & 0.2 & 0.11 & 0.22 \\
\hline $\mathrm{SO}_{3}$ & wt $\%$ & 0.5 & 0.49 & 3.85 & 0.5 & 0.53 & 0.55 & 0.45 & 0.54 \\
\hline $\mathrm{Cl}$ & wt $\%$ & 0.75 & 0.58 & 0.14 & 0.5 & 0.75 & 0.73 & 0.67 & 0.32 \\
\hline $\mathrm{K}_{2} \mathrm{O}$ & wt $\%$ & 2.5 & 2.35 & 0.73 & 2.25 & 3 & 3.27 & 2.25 & 2.57 \\
\hline $\mathrm{CaO}$ & wt $\%$ & 55 & 54.9 & 26.95 & 58 & 60 & 53.13 & 56.55 & 47.35 \\
\hline $\mathrm{TiO}_{2}$ & wt $\%$ & 0.25 & 0.25 & 0.33 & 0.25 & 0.35 & 0.3 & 0.22 & 0.29 \\
\hline $\mathrm{Cr}_{2} \mathrm{O}_{3}$ & wt $\%$ & 0.25 & 0.27 & & 0.45 & 0.25 & 0.34 & 0.21 & 0.17 \\
\hline $\mathrm{FeO}$ & wt $\%$ & 3 & 2.75 & 4.18 & 3.6 & 2.25 & 3.5 & 2.75 & 2.63 \\
\hline $\mathrm{NiO}$ & wt $\%$ & 0.65 & 0.41 & 0.51 & 0.5 & 0.17 & 0.57 & 0.44 & 0.05 \\
\hline Total & & 100 & 100 & 100 & 100 & 100 & 100 & 100 & 100 \\
\hline
\end{tabular}

The sample SJT2-2 was found different with all the other samples being rich in $\mathrm{SiO}_{2}$ content of about $45 \%$ and $\mathrm{CaO}$ $35 \%$, which further supported the petrographic analysis that showed higher aggregate to binder ratio for this particular sample. The $\mathrm{Al}_{2} \mathrm{O}_{3}$ content was found about $8 \%$ with $\mathrm{Fe}_{2} \mathrm{O}_{3}$ content of $3.5 \%$, which is quite similar to the old mortars composition as described above. The $\mathrm{Na}_{2} \mathrm{O}, \mathrm{K}_{2} \mathrm{O}$ and $\mathrm{MgO}$ were also found in similar proportions as in all other samples. The absence of fibrous material in this mortar is also one of the reasons of its low bonding strength.

The chemical analysis of the mortars clearly distinguished the new mortar from the old mortars and further elaborated the cause of its failure (cracks and falling materials at conservation locations) as observed at various locations during the survey. The results clearly depicted the higher binder aggregate ratio of new mortar which is not compatible with the old mortars and can be seen in further microstructure analysis done afterwards $s^{25,26}$. This difference of binder aggregate ratio which can only be determined by the chemical analysis like XRF is the key step in developing the compatible mortars for future conservation works ${ }^{19}$.

The analysis of the mortars by SEM/EDS showed all the mortars (Figs. 3 and 4) have a compact microstructure typical of old lime mortars with aggregates well embedded in the matrices except SJT2-2 where they were found loosely bound $^{26-28}$. The oxide compositional analysis of the mortar samples by EDS (Table-4) indicated that all the mortars were mainly composed of high amounts of $\mathrm{Ca}, \mathrm{Si}$ and moderate amounts of $\mathrm{Al}, \mathrm{Mg}$ and $\mathrm{K}$.

However the amounts of $\mathrm{Fe}$ in all the mortars were found more or less to be the same (Tables 3 and 4). Abundant calcite crystal-amorphous hydraulic formations (CSH) cluster aggregates were determined in the matrix of the mortars ${ }^{29-31}$, especially in the samples SJT2-1, SJT-6 and SJT-7 (Fig. 3a, c and d).

$$
\mathrm{Ca}(\mathrm{OH})_{2}+\mathrm{CO}_{2} \rightarrow \mathrm{CaCO}_{3}+\mathrm{H}_{2} \mathrm{O}
$$

Slaked Lime (soft) $\rightarrow$ Carbonated lime (Hard)

$$
\mathrm{Ca}(\mathrm{OH})_{2}+\mathrm{SiO}_{2} \rightarrow \mathrm{CaO} \cdot \mathrm{Si}_{2} \cdot \mathrm{H}_{2} \mathrm{O}
$$

This reflected the use of abundant limestone fragments (locally known as kankar) as the main aggregate with sand and crushed bricks ${ }^{29-31}$, which was most likely recrystallized

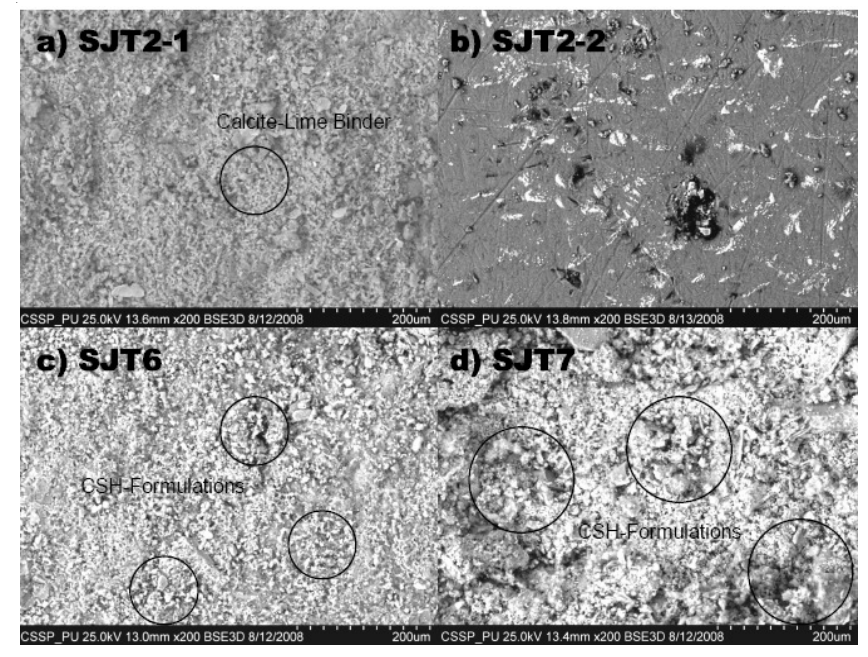

Fig. 3. SEM micrographs of the mortars a) SJT2-1 mortar is showing heterogeneous texture b) SJT2-2 mortar used as a filler afterwards different from the old mortars in texture as shown c) SJT6 showing typical heterogeneous texture d) SJT7 also showing the heterogeneous texture with $\mathrm{CSH}$ aggregates formations

as fine calcite and CSH aggregates and oriented as clusters following the hydration process:

$$
\begin{gathered}
\mathrm{CaO}+\mathrm{H}_{2} \mathrm{O} \rightarrow \mathrm{Ca}(\mathrm{OH})_{2} \\
\mathrm{Ca}(\mathrm{OH})_{2}+\mathrm{CO}_{2} \rightarrow \mathrm{CaCO}_{3}+\mathrm{H}_{2} \mathrm{O} \\
\mathrm{CaCO}_{3}+\mathrm{H}_{2} \mathrm{O} \rightarrow \mathrm{Ca}\left(\mathrm{HCO}_{3}\right)_{2}(\text { soluble }) \\
\mathrm{Ca}\left(\mathrm{HCO}_{3}\right)_{2}+\mathrm{Ca}(\mathrm{OH})_{2} \rightarrow 2 \mathrm{CaCO}_{3}+2 \mathrm{H}_{2} \mathrm{O}
\end{gathered}
$$

The well to moderately uniform distribution of the porosity observed in the SEM images of old mortar samples is probably due to the homogeneous distribution of the hydration process i.e., indicating most likely a uniform proceeding hydration process, mainly composed of calcite and $\mathrm{CSH}^{30,32}$.

The presence of organic fibers also indicates an incremental increase in mortar durability as observed in the SEM image of the sample $e^{13,33}$.

The presence of $\mathrm{Cl}$ (Table 4) which was also indicated in the XRD is not due to the deterioration but it was added as an accelerator for hydration process also supported by textural references ${ }^{17,18,34}$. 

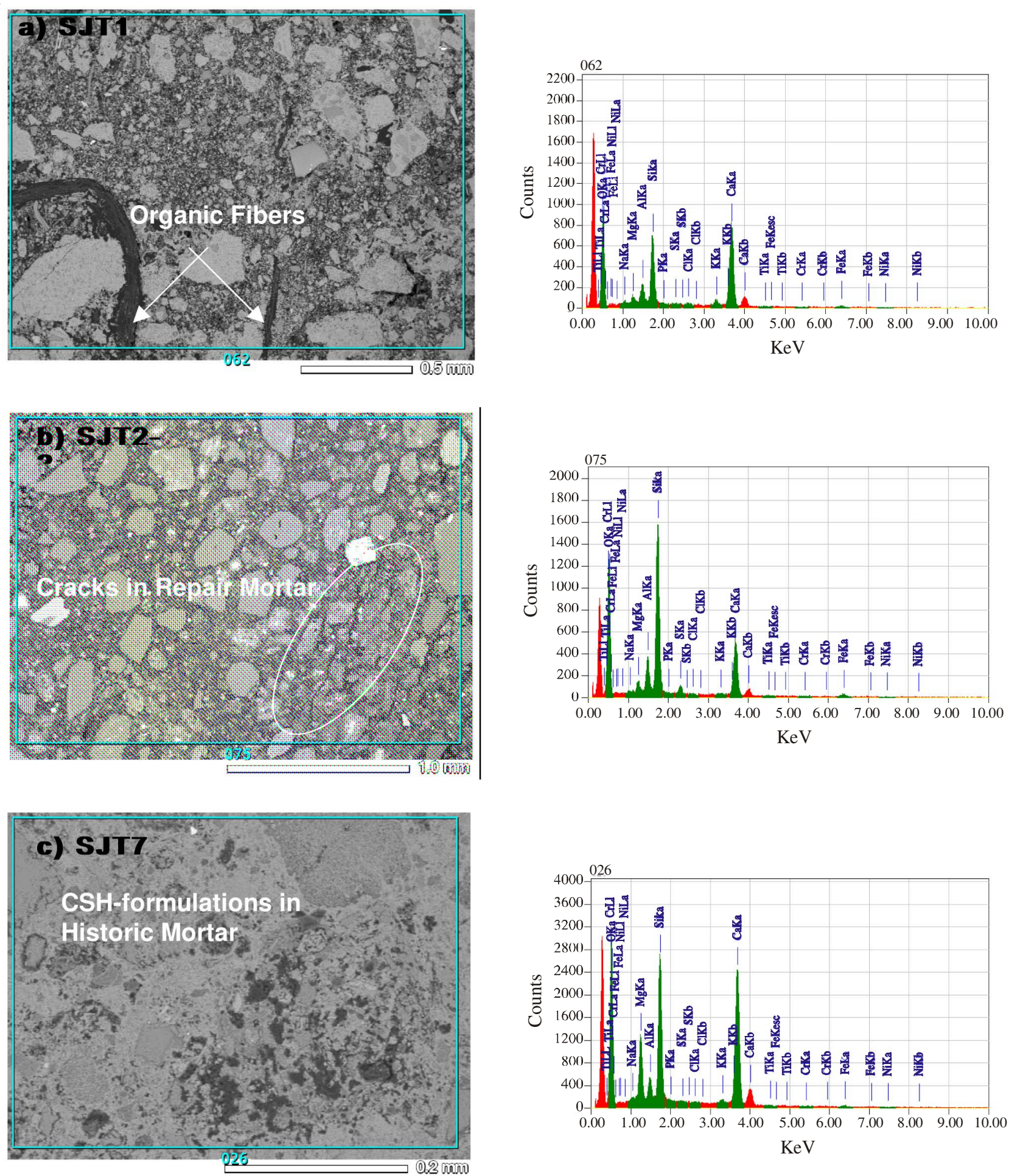

Fig. 4. SEM micrographs of selected samples with corresponding EDS

\section{Conclusion}

This work for the mortars characterization of $17^{\text {th }}$ century Mughal period has shown the calcitic lime was used as binder with broken kankar-limestone fragments, sand and crushed bricks as aggregates. The pulverized brick and sometimes brick kiln slag was added as pozzolanic materials to increase the strength of the mortars which also modifies the pore-structure subsequently increasing the durability. The addition of the jute fibers further improved the bonding strength and durability of these mortars. All the samples except SJT2-2 have similar chemical compositions, which are in agreement with the previous historical research done on $17^{\text {th }}$ century mortars of Mughal period in India (part of the subcontinent). The Sample SJT2-2 showed higher silica and low calcite content depicting it to be the new mortar having 5-6 times higher aggregate content (silica-sand) than the old mortars. The results proved it to be the later addition when the restoration works were first started on this monument in $19^{\text {th }}$ century. Samples SJT4 and SJT5 are composed of one uniform layer consisting of fine aggregates applied as renders, which is finished with rich lime 
finishing coats afterwards. This was a common technique to improve protection of ancient masonry against weathering agents.

The aggregates used in all the mortars have a mineralogical composition identical to the locally available materials supported by the geology of the area.

\section{ACKNOWLEDGEMENTS}

The authors thank the staff of the Department of Archaeology and Museums for their help during the field observations and sampling. Thanks are also due to Department of Earth Sciences ETH-Zurich, for their assistance in XRF and SEM-EDS analysis, respectively.

\section{REFERENCES}

1. H.S. Jarrett, Ain-i-Akbari by Abul Fazl, Oriental Books Reprints Corporation, New Dehli, pp. 35-79 (1978).

2. R. Nath and Jharoka (An illustrated Glossary of Indian-Muslim Architecture)-The Historical Research Documentation Program, India, pp. 13-53 (1986).

3. A. Rehmani, M.A. Thesis, History and Architecture of Mughal Monuments at Shahdara, University of the Punjab, Lahore, pp. 12-35 (1976).

4. M.S. Khan, M. Ahmad and M.A. Khan, Lahore Museum Bull., 13, 115 (2000).

5. B. Fielden, Guidelines for Conservation- A Technical Manual, The Indian National Trust for Arts and Cultural Heritage, Delhi, pp. 55-56 (1989).

6. G. Chiari, G. Torraca and M.L. Santarelli, Standards for preservation and rehabilitation. ASTM 1996; STP 1258, pp. 275-278 (1996).

7. J. Hughes and K. Callebaut, Practical Sampling of Historical Mortars. Proceedings of the RILEM International Workshop Historic Mortars: Characteristics and Tests. Paisley, Scotland, pp. 17-26 (2000).

8. M.R. Veiga, J. Aguiar, A. Santos Silva and F. Carvalho, Methodologies for Characterization and Repair of Mortars of Ancient Buildings. Proceedings of the 3rd International Seminar on Historical Constructions, Guimarães, pp. 353-62 (2001)

9. J. Elsen, Cem. Concr. Res., 36, 1416 (2006).

10. J.E. Lindqvist and M. Sandström, Mater. Struct., 33, 612 (2000).

11. B. Schouenborg, J.E. Lindqvist, M. Sandström, K. Sandin and E. Sidmar, Analysis of Old Lime Plaster and Mortar from Southern Sweden - A Contribution to the Nordic seminar of building limes. Swedish National Testing and Research Institute, Building Technology, Sp Report 1993: p. 34 (1993).

12. J. Ahsan, Building Construction in Mughal India; Composition and properties of Historic Lime Mortars, 16th Congress on Deterioration and Conservation of Stone, p. 484 (1981)

13. M. Aslam, M.L. Tabasso, P.L. Bian Chatti and A.E. Charole, Studies of Lime Plasters and Mortars of Taj Mahal, 8th Triennial meeting, Sydney, Preprint, Vol. 2 (1987)

14. G. Mertens, J. Elsen, R. Brulet, A. Brutsaert and M. Deckers, Mater. Charact., 60, 580 (2009).
15. S. Gulzar, M.Sc. Thesis, Environmental Effects on Cultural Heritage: Shahdara Complex-Lahore, University of the Punjab, Lahore, pp. 5789 (2004).

16. M.J. Singh, K. Kamal, T. Singh and I.K. Bhatnagar, A Preliminary investigation on the development of suitable gap filling material for the restoration of historic building, No., 1, Pragdhra, J.U.P. State Archaeological Organization, Ed. Rakesh Tewari, Lucknow, U.P., India (1991).

17. D. Benedetti, S. Valetti, E. Bontempi, C. Piccioli and L.E. Depero, Appl. Phys., 79(A), 341 (2004).

18. R. Castelló, P. Morillas, C. Vizcayno, J. Martín-Rodríguez, Centro de Ciencias Medioambientales, Csic, Characterization of rendering mortars on some buildings of Toledo, Spain, 3rd International Congress on Science and Technology for the safeguard of Cultural Heritage in the Mediterranean Basin, Alcalá de Henares, Spain, July 9-14, (2001).

19. J.I. Alvarez, I. Navarro and P.J.G. Casado, Thermochim. Acta, 365, 177 (2000).

20. J. Webera, W. Prochaskab and N. Zimmermannc, Mater. Charact., 60, 586 (2009).

21. H. Böke, S. Akkurt, B. Ipekoglu and E. Ugurlu, Cem. Conc. Res., 36, 1115, (2006).

22. S. Prakash and N.S. Rawat, Chemical Study of Some Indian Archaeological Antiquities, Bombay, pp. 7-19 (1965).

23. Sanne Ullah, Composition and Properties of Historic Lime Mortars, 16th International Congress on Deterioration and Conservation of Stones, Proceedings Actes, pp. 484-486 (1995).

24. R.S. Gupta, Structural Consolidation of Monuments; Conservation in Tropics, Heritage Conservation, Mortars used in Ancient Buildings. pp. 167-201 (1953).

25. M.S. Vast, Repairs at Agra and Fatehpur Sikri, Ancient India, A Bulletin of Architectural survey of India, No. 6 pp. 93-99 (1949).

26. S. Pavía and S. Caro, Const. Build. Mater, 22, 1807 (2008).

27. S. Sánchez-Moral, L. Luque, J.C. Cañaveras, V. Soler, J. Garcia-Guinea and A. Aparicio, Cem. Conc. Res., 35, 1555 (2005).

28. J.Ashurst and N. Ashurst, Mortars, plasters and renders. Practical Building Conservation Vol 3. English Heritage Technical Handbook. Aldershot, Hampshire, United Kingdom: Gower Technical Press, (1989).

29. I.C. Zamba, M.G. Stamatakis, F.A. Cooper, P.G. Themelis and C.G. Zambas, Mater. Charact., 58, 1229 (2007).

30. M. Radonjic, K.R. Hallam, G.C. Allen and R. Hayward, Mechanism of Carbonation in Lime-Based Mortars. Proc $8^{\text {th }}$ Euroseminar on Microscopy Applied to Building Materials. Athens; pp. 465-75 (2001).

31. E.M. Chamot and C.W. Mason, Handbook of Chemical MicroscopyChemical Methods and Inorganic Qualitative Analysis, vol. 2. New York: John Wiley and Sons Inc.; 1946. Republished by McCrone Research Institute, Chicago, IL (1989).

32. M. Singh, K.K. Jain and T. Singh, Some Studies on the Suitability of Lime Mortars based on Ancient Indian Formulations for Restoration Purposes, Superflict dell Architecturs, La Finiture, Bressanone, pp. 151158, (1990).

33. H.L. Uppal and M. Singh, Indian Conc. J, 8, 246 (1995).

34. U.C. Kalia, B.G. Bathakar, K.G. Nambiar and J.N. Baruch, Building Materials and Building Techniques, Seminar on Building Materials, February 1985, Regional Research Laboratory, Bhopal, India (1985). 